\title{
Learning Management Systems (LMS): Inside Matters
}

\author{
Shakeel Iqbal*, Ijaz A. Qureshi \\ Iqra University, Islamabad Campus, Pakistan \\ *siqbal@iqraisb.edu.pk
}

\begin{abstract}
By the end of last millennium, many universities and colleges started using internet to meet their distance learning needs. Different course management systems (CMS) were developed to meet the needs of online and hybrid courses. These CMS later on transformed into Learning Management Systems (LMS). Many educational institutions have already started using LMS and there are still many who are considering adopting one. The big question before the late adopters of this online learning technology is which LMS they should opt for? This study will be useful for those who are in the process of selecting an LMS as well as those who are in the business of designing one. A survey was conducted to get feedback from the faculty of higher education institutions to find out the major barriers in adoption of e-learning and to find out what kind of functionalities and teaching methodologies should be supported by LMSs. Results indicate lack of training, lack of incentives to use e-learning, lack of technical support and lack of time to develop e-courses are the major barriers in adoption of e-learning by the faculty members. As far as the desired functionalities in an LMS are concerned ability to create student groups for group activities, availability of discussion board, announcement board and online quizzes, file sharing/transfer functionality were the most sought functionalities. The most desired method of teaching that need to be supported by LMS had been group problem solving, discussion based strategies, problem based learning and simulation. The results of survey will be helpful for the adopter as well as designers of LMS.
\end{abstract}

Key words: learning management systems, course management systems, design, pedagogy

\section{Introduction}

Before the advent of World Wide Web (WWW) many universities and colleges were using offline resources, such as CD ROMS and pre-recorded sessions, as well as online resources like satellite and closed circuit television for distance learning. When Internet became popular in 1990s, it unleashed the potential of using Internet in education (Fuller et al., 2000). New forms of internet-based learning were developed: complete online courses; hybrid courses in which some classes are online and some face to face; and technology enhanced courses where primary method of teaching is face to face but online resources are also used to enhance learning experience (Horton, 2000). At the start of this millennium, online education was realized as a competitor of brick and mortar campus. Many teachers started viewing internet as a tool of learning and teaching and not just a container of information (Burniske and Monk, 2001). Some of the limitations of classroom-based teaching such as dependency on textbook as well as lack of communication between the expert and the student paved the way for Web Based Education (WBE) (Darbhamulla \& Lawhead, 2004). Using internet as a medium of instruction may be attributed to the availability of Learning Management Systems (LMS). Recently, many universities have started using LMS to support their courses (Yueh and Hsu, 2008).

An LMS, as defined by Oakes (2002) is "learner and organization focused: It's concerned with the logistics of managing learners, learning activities and the competency mapping of an organization." LMS covers a wide range of activities and "in an information age model of education an LMS will assess learner's current knowledge and skill level, work with teachers and learners to identify appropriate learning goals, identify and sequence instruction appropriate for the individual learner, assess learner performance products, store evidence of attainments, support collaboration and generate reports to provide information to maximize the effectiveness of the entire learning organization" (Watson \& Watson, 2007). 
Difference between CMS and LMS: Course Management Systems (CMS) were introduced in the 1990s which later on evolved into LMS. Both terms are often used as synonym to each other but in reality they are not. A CMS is more focused on the contents and delivery of the course, whereas an LMS is more focused on the learning need and achievement of a person (Simonson et al., 2006). An LMS emphasizes more on learning management instead of course management and is better suited to meet the needs of an e-learning instructor's tasks (Ceraulo, 2005). Joomla is an example of CMS, whereas Desire2Learn and HotChalk are the examples of LMS (Joomla, 2011; Desire2learn, 2011; HotChalk, 2011).

Advantages of an LMS: Some of the main advantages from the students' as well as instructors' point of view are summarized in table 1 given below:

Table 1: Advantages of an LMS

\begin{tabular}{|c|c|c|}
\hline S.NO & Advantages for Students & Advantages for Teachers \\
\hline 1 & $\begin{array}{l}\text { Single spot availability of all course } \\
\text { related information. }\end{array}$ & $\begin{array}{l}\text { Convenience in providing additional resources to } \\
\text { students besides class lectures. }\end{array}$ \\
\hline 2 & $\begin{array}{l}\text { Easy access to information - anywhere, } \\
\text { anytime. }\end{array}$ & Access to students other than class timings. \\
\hline 3 & $\begin{array}{l}\text { Convenience in keeping track of progress } \\
\text { in a course. }\end{array}$ & $\begin{array}{l}\text { Timely feedback can be provided to students on } \\
\text { their progress in a particular course. }\end{array}$ \\
\hline 4 & $\begin{array}{l}\text { Availability of practice questions and } \\
\text { suggested solutions make learning more } \\
\text { engaging and practical. }\end{array}$ & $\begin{array}{l}\text { Better monitoring of students is possible as it is } \\
\text { easy to keep track of all assignments - submitted } \\
\text { as well as not submitted. }\end{array}$ \\
\hline 5 & $\begin{array}{l}\text { Ease of arranging off campus meetings } \\
\text { with instructor and class mates in a } \\
\text { virtual environment. }\end{array}$ & $\begin{array}{l}\text { It offers a good platform for using innovative } \\
\text { ideas in teaching. }\end{array}$ \\
\hline
\end{tabular}

An LMS offers a wide range of functionalities and tools to support teaching and learning. It not only delivers contents but also looks after administration, registration, tracking, skills gap analysis and reporting (Gilhooly, 2001). Still there are many universities who are in the process of selecting an LMS. According to McConachie, Danaher, Luck, and Jones (2005) selection of an LMS is the most important factor to decide any university's online success.

\section{Literature Review}

Fertalj et al. (2006) conducted a comparison of four types of LMSs available in the market: Proprietary LMS, mainly proprietary and partly standard based LMS, mainly standard based LMS and partly proprietary LMS and open architecture LMS. They concluded that "standard/proprietary" systems were leading the e-learning market and they expected the trend to continue in future as well, but they emphasized upon the potential investors to be cautious about the level of conformity of specific LMS they are intending to adopt with the standards such as SCORM. Some researchers have studied the usage of LMS functions by the faculty members. In one of the studies a survey of 862 faculty members at 38 institutions who used the Blackboard Learning Management System was conducted (Woods et al., 2004). It was concluded that only a few faculty members used LMS functions to assess students or to promote community. The faculty was reported to use mostly the instructional functions such as providing readings, publishing syllabi and sending emails, whereas the interactive and communicative features were rarely used. In another study conducted by Grant (2004) some faculty members informed of using Blackboard Course Info to post scanned material in the absence of the copying services.

Review of literature on the topic also indicates that some researchers have focused on discussing the pedagogical styles supported by an LMS. There is a general assumption that the more features an LMS has there is a more likelihood of it being selected. This assumption will encourage vendors to include more and more features in an LMS without taking into consideration the underlying pedagogical principles (Govindasamy, 2002). LMS are often criticized for ineffective usage. It is not that LMS are used ineffectively, because of the bad design rather lack of pedagogical skills of the instructor is the main factor most of the time (Vrasidas, 2004). Several strategies for enhancing the use of deep learning methods through learner-centered 
learning are found in the literature such as collaborative learning (McConnell, 2005; Migadadi, 2009), interactive learning (Salajan et al., 2009), explorative learning (Dicheva and Dichev, 2006), adaptive learning (Brusilovsky and Peylo, 2002), use of concept mapping techniques (Conole et al., 2008), and blended learning (Alonso et al., 2005). The success of these strategies depends on the effective integration of information and communication technologies (ICT) in e-learning (Yang, 2008).

What's Inside an LMS?: Selection of an LMS is dependent upon many factors - such as organizational needs and requirements, availability of appropriate technical support and LMS capabilities. A review of literature on the factors considered most important for selection of an LMS indicates the following four factors: Organizational goals and objectives, Technical support and specifications, LMS Design and functionalities and Pedagogical support provided by an LMS.

\section{Figure 1: Cross Sectional View of an LMS}

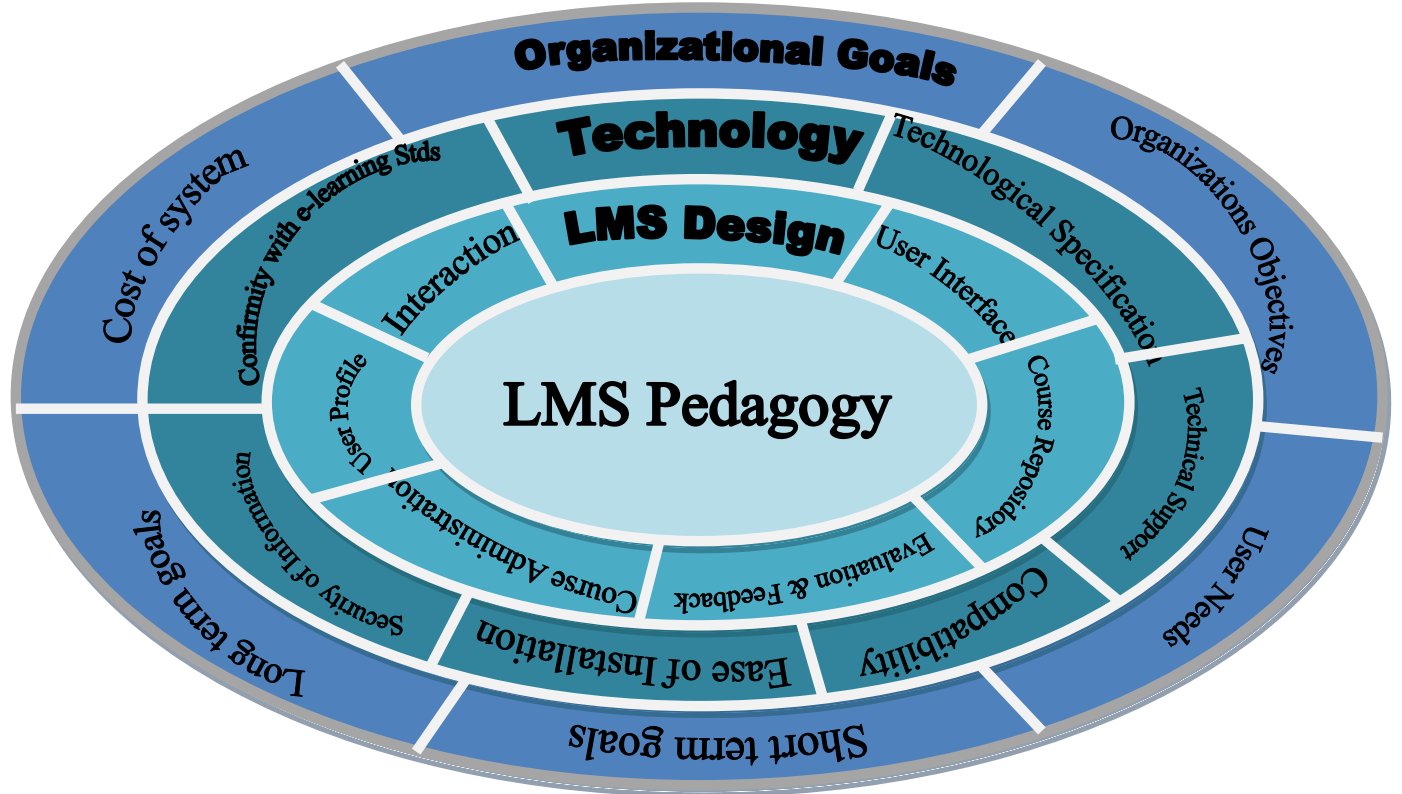

Four factors that are most important for the selection of an LMS are discussed below:

Organizational Goals and Objectives: What an LMS offers is more important than how it is being offered. In case of e-learning, most of the time people emphasize more on the "e" part and ignore the learning part (Middleton, 2010). Organizations selecting an LMS should be clear about the objectives they want to achieve by means of LMS. Those interested in introducing an LMS should list down their short term as well as long term objectives and then decide which LMS is best suited to meet these objectives. Unless these objectives are clear, introduction of an LMS would be a futile effort (Ismail, 2002). Besides suitability to meet short and long term objectives of an organization, the cost of LMS should also be within the budgetary constraints of the organization.

Technical Specifications and Support; Initiating any e-learning program without proper technical support will end up in disaster (Selim, 2007). Any LMS that an organization is going to select should be compatible with the system currently being used, and it should be easy to install and operate. Since LMS requires a lot of confidential information to be uploaded and stored, the network should be fully secured to prevent unauthorized and malicious usage (Zhang and Nunamaker, 2003). Another very important aspect that should be taken into consideration while selecting an LMS is to see that it is compatible with e-learning standards such as Sharable Content Object Reference Model (SCORM) (Sanchez-Alonso \& Frosch-Wilke, 2005).

Design Specifications of an LMS: The two factors discussed above can be considered as organizational factors playing role in the selection of an LMS. The design specifications which include functionalities and 
pedagogical style supported by LMS also play an important role in the selection of an LMS. Some of the important aspects of design specification of an LMS are discussed below.

Clear and User Friendly Graphical Interface: The first interaction between a user and an LMS will be by means of its graphical interface. A well designed interface with clear instructions encourages the use of an LMS or the reverse could happen if the user interface is not properly designed. User interface should give a clear picture of what different functionalities are there for users to get advantage from. A good user interface is the one which is easy to navigate and contains appropriate type of multimedia (Galitz, 2007). Simple navigation is needed in an LMS since it keeps learners from getting lost and will help the learners achieve their goals. An instructor needs an LMS that will minimize frustration and maximize learning (Lewis et. al, 2005). The users should be able to customize the design of screen according to their taste and preferences. This will help in preventing the instructional process from becoming dull and monotonous (Kang et al., 2000)

Well Designed Course Repository; An LMS should have a well defined course contents area where an instructor should be able to upload and save all course related material. It should support a variety of file formats such as .ppt, .pdf, .doc, etc., so that the teacher should be able to upload his files containing lecture notes, slides, multimedia, and PowerPoint. It should also offer the functionality where a teacher can upload the practice questions and suggested solutions to make learning more engaging. The array of tools and functions provided by an LMS are there to support both the learners and teachers which include course management tools, homework collections and grading, course evaluation, online group chat and discussion (Yueh and Hsu, 2008). Some of the features offered by LMS are technically more sophisticated such as reminding students about the deadlines, holding virtual office hours, and dividing students into groups for online projects (Yildirim et al., 2004).

Course Administration Capability: LMS should provide the authority to the instructors to control the registration of courses. There should be an area where the instructor could save all the information related to a student - registration of courses, payment of fees, attendance record, grade record, etc. All of this information should be confidential and password protected. LMS should also offer the facility of making backup of all the data so that in case of any accident or crash all the data is secure. The system should also be able to build schedules for learners, instructors, and classrooms (Greenberg, 2002).

Capability of Interaction among the Users of LMS: An LMS should offer interaction among the students and teacher. There should be an announcement area where important announcements related to a course should be posted and are accessible to all the users. There should be a discussion board where the students can post their views and opinions about any assigned topic of discussion. These discussion forums can change the students from "passive viewers to active participants" (Henderson, 2003). It should also offer audio/video conferencing facility to the users. The instructor should be able to create groups of the users to carry out any group activity. LMS should also offer social networking capabilities by means of blogs, wikis, etc. Students should be provided the opportunity to communicate with the instructor or other students by using e-mail, bulletin boards, and live chat rooms (Hazari, 1998).

Evaluation and Feedback; Students should be able to upload their assignments and quizzes via LMS. There needs to be a digital drop box where students could submit their work. There should be a mechanism through which all the submissions by the students are graded and reported back to the students. There should be of variety of ways of testing the knowledge of students and it should also offer test management capabilities. The advantage of online assessment, also known as e-Assessment, is to provide instant feedback to students, thus enabling them to take immediate action to 'close the gap' between their current performance and desired performance (Ramaprasad, 1983; Sadler, 1989).

Student's Profile: LMS should offer the capability to maintain the complete profile of all the users. The instructor should be able to get full information about a student: picture, registration details, competence level, attendance record, work submitted, missed assignment, grading. According to Carliner (2005) LMSs were designed to primarily for workplace learning environment and perform some or all of the following tasks: registration, track participation, track of completion, testing, follow-up discussion, maintenance of payment record, generation of different reports related to courses, etc. 
Colace et al. (2003) identified and listed the following functionalities of LMS: Progress tracking, multiple course management, hyper textual courses, student group creation and management, content inclusion in accordance with standards, content importation, new course creation in accordance with standards, course indexing, course importation from other producers, reports on course frequency or utilization, test creation, course catalogue, multiple choice tests, reports on test results, online registrations, access rights assignment and username and password assignment. Kim and Lee (2007) identified seven factors for evaluation of LMS: appropriate design of screen and system, user accessibility, variety of test types and communication, system interoperability, ease of use of course procedures, flexibility of interaction, appropriateness of multimedia and ease of instruction management. Schmidt (2002) mentioned the following four components as critical for successful enhancement of an online course: administrative component, assessment component, content component and community component. These components can enhance learning/teaching experience but they cannot replace the traditional classroom experience.

The Core of LMS: Pedagogy; The most important component of an LMS, which we are referring here as the core of LMS, is the pedagogical styles supported by it. It would be unfair to compare and evaluate LMS on the basis of feature richness alone. One of the recommended pedagogical approaches for online learning is constructivist approach. It is an approach where students build up their knowledge by applying their existing knowledge to new situations and thus learn new things in the process. It is easy to incorporate constructivist approach in online learning platforms, because online platforms are well suited to encourage and engage students in dialogue with the teacher as well as students, to support student's initiative and autonomy, and to provide immediate feedback (Jonassen et. al, 1999). By reviewing the work of different educationists, Carmean and Haefner (2002) came up with a core set of deeper learning principles. They assert that "deeper learning" or engaged learning result in a better understanding of concepts when learning is social, active, contextual, engaging and student owned. These five principles are discussed with reference to LMS in the table given below:

Table 2: Deeper Learning Principles in LMS perspective (adapted from Carmean and Haefner, 2002)

Learning is When.... How these objectives can be achieved
in an LMS environment

\begin{tabular}{|c|c|c|}
\hline Social & $\begin{array}{l}\text { It encourages contact between students and } \\
\text { faculty. }\end{array}$ & $\begin{array}{l}\text { Virtual chat, discussion boards, } \\
\text { announcement postings. }\end{array}$ \\
\hline Active & $\begin{array}{l}\text { Practice and reinforcement are emphasized. } \\
\text { Involvement in real-world tasks is emphasized. }\end{array}$ & $\begin{array}{l}\text { Interactive testing modules can be used } \\
\text { where answers can be evaluated and } \\
\text { immediate feedback provided to } \\
\text { students. }\end{array}$ \\
\hline Contextual & $\begin{array}{l}\text { New knowledge is integrated into the learner's } \\
\text { world. } \\
\text { New knowledge is demonstrated to the student. }\end{array}$ & $\begin{array}{l}\text { Use of hyperlinks to carefully chosen web } \\
\text { sites to direct students to additional } \\
\text { information. } \\
\text { Requiring students to construct } \\
\text { presentations of the new knowledge and } \\
\text { share those presentations with peers and } \\
\text { experts in the knowledge domain. }\end{array}$ \\
\hline Engaging & $\begin{array}{l}\text { It respects diverse talents and ways of learning. } \\
\text { It is done in high-challenge, low-threat } \\
\text { environments. }\end{array}$ & $\begin{array}{l}\text { Use of audio/visual tools, multimedia. } \\
\text { Use of Synchronous as well as } \\
\text { asynchronous learning tools. }\end{array}$ \\
\hline $\begin{array}{l}\text { Student- } \\
\text { owned }\end{array}$ & $\begin{array}{l}\text { Students take control of their own learning: } \\
\text { noting failures, planning ahead, apportioning } \\
\text { time and memory to tasks. } \\
\text { It emphasizes learner independence and choice. }\end{array}$ & $\begin{array}{l}\text { Enhancing students' ability to seek } \\
\text { answers quickly. }\end{array}$ \\
\hline
\end{tabular}

The traditional material for distance learning i.e., audio-video tapes, printed material and broadcast media is too structured and rationalized (Peters, 2001). There is a need of using specific techniques or mediating tools to make the learning effective by increasing interaction between the instructor and students and by reducing 
transactional distance between them. A great deal of discussion on pedagogical design in e-learning is focused on the role of social aspect of learning (Haythornthwaite, 2000; Good, 2001).

\section{Methodology}

A survey was conducted among the faculty members of public and private sector universities. The purpose of the survey was to find out the answers to following three questions: 1) What are the main barriers in elearning adoption as far as the faculty is concerned? 2) What are some of the functionalities that need to be there in an LMS? 3) What are the main pedagogical methods that should be supported by an LMS?

A total of 200 questionnaires were distributed in person and through email to the faculty members of different universities which included both the private and public sector universities. The sampling technique used was convenient sampling. The questionnaire was divided into four sections: Section 1 recorded the demographic profile of respondents, Section 2 recorded the faculty responses with respect to the barriers they consider most important for adoption of e-learning in higher education, Section 3 was designed to record the faculty responses with respect to their desired functionalities of an LMS and Section 4 captured the teaching methodology to be supported by LMS. The respondents were asked to reply to the options in section 2, 3 and 4 on a scale of 1 to 10 where 1 was considered least important and 10 was considered to be most important.

\section{Results and Discussion}

A total of 98 responses were received which were complete and considered fit for the purpose of this study. The following table illustrates the demographic profile of the respondents:

Table 3: Demographic profile of respondents

\begin{tabular}{|c|c|c|c|}
\hline & & Frequency & Percent \\
\hline \multirow[t]{3}{*}{ Type of university } & Private sector university & 22 & 22.4 \\
\hline & Public sector university & 76 & 77.6 \\
\hline & Total & 98 & 100.0 \\
\hline \multirow[t]{6}{*}{ Department } & Art \& Humanities & 10 & 10.2 \\
\hline & Engineering & 19 & 19.4 \\
\hline & Management sciences & 38 & 38.8 \\
\hline & Medical & 10 & 10.2 \\
\hline & Social sciences & 21 & 21.4 \\
\hline & Total & 98 & 100.0 \\
\hline \multirow[t]{4}{*}{ Position } & Associate professor/Professors & 12 & 12.2 \\
\hline & Assistant professor & 30 & 30.6 \\
\hline & Lecturer & 56 & 57.1 \\
\hline & Total & 98 & 100.0 \\
\hline \multirow[t]{4}{*}{ Education } & Masters & 40 & 40.8 \\
\hline & MS/M.Phil. & 37 & 37.8 \\
\hline & Ph. D & 21 & 21.4 \\
\hline & Total & 98 & 100.0 \\
\hline \multirow{5}{*}{$\begin{array}{l}\text { Teaching experience at } \\
\text { university level }\end{array}$} & $1-3$ years & 40 & 40.8 \\
\hline & $3-5$ years & 20 & 20.4 \\
\hline & Less than one year & 12 & 12.2 \\
\hline & More than 5 years & 26 & 26.5 \\
\hline & Total & 98 & 100.0 \\
\hline \multirow{5}{*}{$\begin{array}{l}\text { Current status of e-learning } \\
\text { at your university }\end{array}$} & Complete online classes & 3 & 3.1 \\
\hline & Face to face classes only & 49 & 50.0 \\
\hline & Face to face classes with web based & 41 & 41.8 \\
\hline & support & 5 & 5.1 \\
\hline & $\begin{array}{l}\text { Hybrid classes: some face to face and some } \\
\text { online classes } \\
\text { Total }\end{array}$ & 98 & 100.0 \\
\hline
\end{tabular}




\section{Figure 2: Barriers Faced by Faculty in Adopting E-Learning}

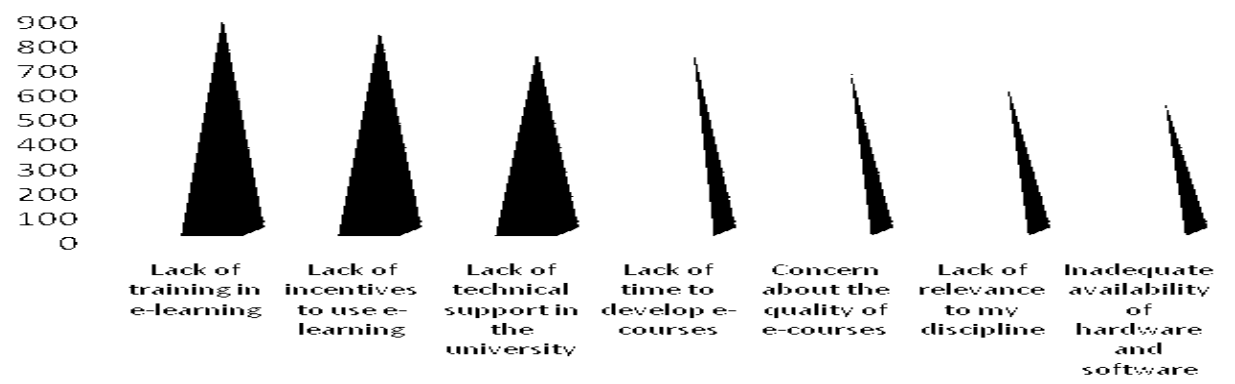

Figure 2 shows the summary of faculty responses with respect to the question that what are the main barriers being faced by them in adopting e-learning. Lack of training on e-learning, lack of time to develop elearning courses and lack of technical support in the university were considered to be the top three most important barriers in adoption of e-learning. These factors have been identified as a barrier in some other studies as well. For example, Lack of training in e-learning is one of the barriers identified in by Muir-Herzig (2004); increased time commitment in e-learning is identified as a barrier in adoption by Messing (2002) and Young (2002); lack of incentives and rewards is identified as a barrier by Lee(2001) and lack of technical support and lack of time to develop materials is identified as a barrier in adoption of e-learning by Naidu (2004).

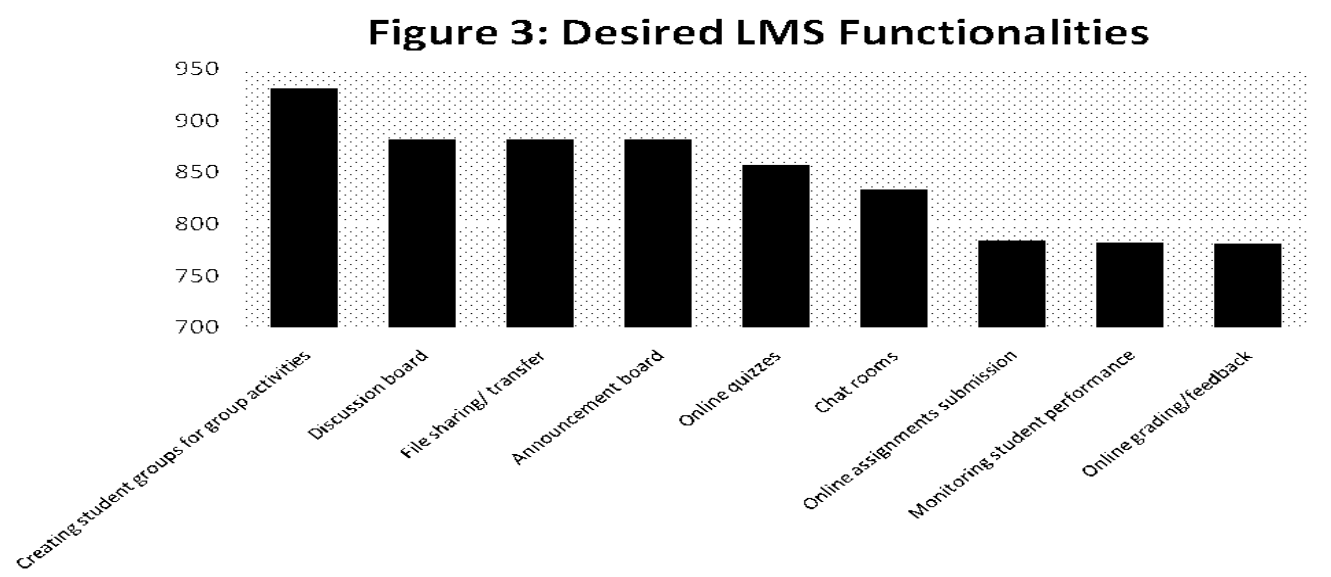

Figure 3 shows the desired functionalities in an LMS. Based on the feedback from the respondents the functionalities can be ranked in descending order as creating student groups for group activity, availability of discussion board, file sharing/transfer facility, announcement board, online quizzes, chat rooms, online assignment submission, monitoring student performance, online grading /feedback. Currently LMSs available in the market are offering many functionalities majority of which are rarely used. The functions which are most frequently used in an LMS environment are not necessarily the technically advanced ones (Woods et. al, 2004). The functions mostly used in LMS are related to communicating course information to students and faculty. The same is found in current research that the faculty prefers course information sharing tools (such as discussion board, file sharing/transfer facility, announcement board) over course assessment and monitoring tools (such as online quizzes, online assignment submission, monitoring student performance, online grading / feedback). 
Figure 4: Teaching Methodology

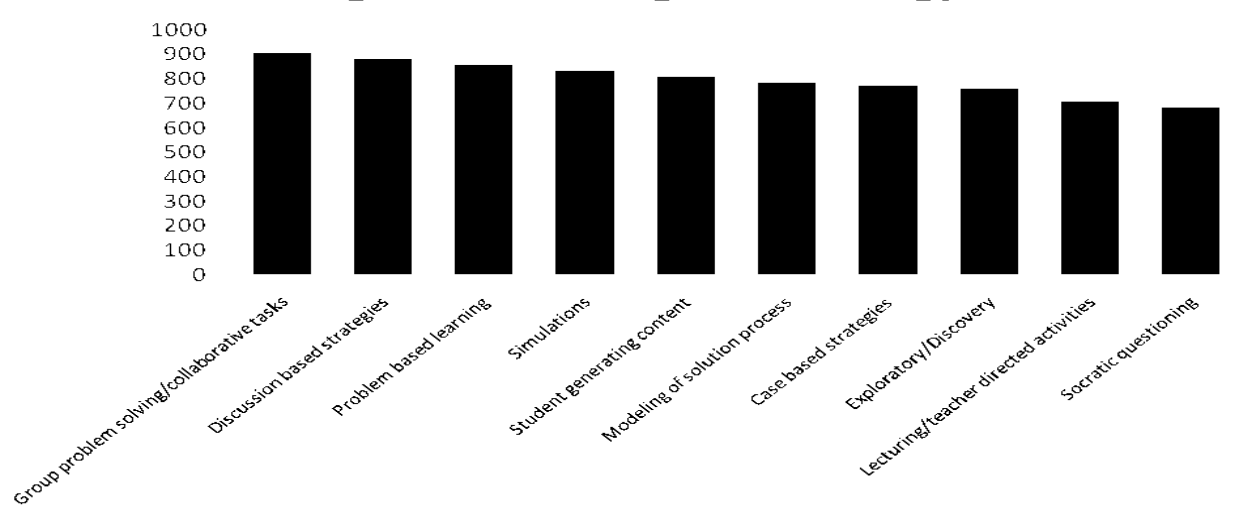

Figure 4 summarizes the respondent's feedback with respect to teaching methodology they prefer to be supported by an LMS. The teaching methodologies in order of desirability from most desired to least desired can be ranked as follows: Group problem solving, discussion based strategies, problem based learning, simulations, student generating content, modeling of solution process, case based strategies, exploration/discovery, lecturing/teacher directed activities and Socratic questioning. This indicates that majority of faculty would prefer online collaboration, problem-based learning (PBL), simulations and casebased learning, rather than the traditional approaches such as lecturing/teacher directed activities or Socratic questioning for their online teaching. In other words, current survey depicts that more learnercentered techniques are preferred by the faculty; indicating a marked shift from traditional teacher-directed approaches (Kim \& Bonk, 2006).

LMS should be designed to fulfill the following learning/teaching requirements (Reigeluth and Garfinkle, 1994; Taylor, 2004):

a) Offer flexible learner-defined goals.

b) Support constructivist-based instructions.

c) Enable personalized assessment and feedback and maintenance of progress.

d) Offer collaborative learning environment both at school and away and further involve parents in it.

\section{Conclusion and Recommendations}

Any organization which is in the process of selecting an LMS should answer the following questions first to have a clear idea what they want to achieve from LMS: What are the short term and long term goals to be achieved from the LMS? What is their allocated budget for the LMS? What is the state of technology currently being used in their organization? What type of technical support and security arrangements need to be made for LMS to run smoothly and safely? After listing down the answers to these questions the next step is to look for the design aspects and pedagogical styles supported by the LMS under consideration. In design aspects we have come up with six functionalities that should be there in the LMS to be selected: User friendly and elaborated interface, well designed course repository, course administrative tools, tools and technology to support interaction between instructor and students, capability to test students in different ways and provide timely feedback, and ability to store complete profile of the students. In pedagogy we discusses how deeper or engaged learning can be achieved using LMS. Using LMS for management of learning and learner's related information demands new skill set from both the instructors as well as students. Another very important thing to be kept in mind is that LMS are very good in keeping track of learning and progress of students but they are not a tool to encourage useful interactive learning. There need to be a desire and motivation from the students to learn only then these systems will achieve their desired objectives.

This research has been limited in the sense it focused only on identifying the key functionalities and desired pedagogical support to be offered by the LMSs in general. Future research can be conducted to identify the most desired set of functionalities and pedagogical support required in specific disciplines such as medical, 
engineering, business studies, etc. Also future researchers can link specific tools of LMS needed to support a specific pedagogical style to make LMS more effective.

\section{References}

Alonso, F., Lopez, G., Manrique, D. \& Vines, J. M. (2005). An instructional model for web-base e-learning education with a blended learning process approach. British Journal of Educational Technology, 36(2), 217-35.

Brusilovsky, P. \& Peylo, C. (2002), Adaptive and Intelligent Web-based Educational Systems. International Journal of Artificial Intelligence in Education, 13, 156-169.

Burniske, R. W. \& Monke, L. (2001). Breaking Down the Digital Walls. Albany, NY: State University of New York Press.

Carliner, S. (2005) Course Management Systems Versus Learning Management Systems. Available at http://www.learningcircuits.org/2005/nov2005/carliner.htm. Accessed August 12, 2011.

Carmean, C. \& Haefner, J. (2002). Mind over Matter - Transforming Course Management Systems into Effective Learning Environments, Educase Review, Nov/Dec, 27-34.

Ceraulo, S. C. (2005). Benefits of Upgrading to an LMS. Distance Education Report, 9(9), 6-7.

Colace, F., De Santo, M. \& Vento, M. (2003) Evaluating On-line Learning Platforms: a Case Study, Proceedings of the $36^{\text {th }}$ Hawaii International Conference on System Sciences.

Conole, G., de Laat, M., Dillon, T. \& Darby, J. (2008). Disruptive technologies, pedagogical innovation: what's new findings from an in-depth study of students' use and perception of technology. Computers \& Education, 50(2), 511-24.

Darbhamulla, R. \& Lawhead, P. (2004). Paving the Way towards an Efficient Learning Management System, ACMSE'04, April 2-3, Huntsville, Alabama, USA.

Desire2Learn (2011) retrieved from http://www.desire2learn.com/ on August 16, 2011.

Dicheva, D. \& Dichev, C. (2006), TM4L: creating and browsing educational topic maps. British Journal of Educational Technology, 37(3), 391-404.

Fertalj, K. , Jerković, H. \& Hlupić, N. (2006). Comparison of e-Learning Management Systems Proceedings of the 5th WSEAS International Conference on E-ACTIVITIES, Venice, Italy, November 20-22, 2006, 189194.

Fuller, D., Rena, F. N., Pearce, K. \& Strand, S. (2000). Internet teaching by style: Profiling the online professor.Educational Technology \& Society, 3(2), 71-85.

Galitz, W. O. (2007). The Essential Guide to User Interface Design: An Introduction to GUI Design, Third Ed. Wiley Publishing, Inc.

Gilhooly, K. (2001). Making e-learning Effective. Computerworld, 35(29), 52-53.

Good, M. (2001). On the way to online pedagogy', in J. Stephenson (ed.) Teaching and Learning Online, London: Kogan, $165-74$.

Govindasamy, T. (2002). Successful Implementation of e-learning Pedagogical Considerations, Internet and Higher Education, 4, 287-299.

Grant, M. (2004). Learning to teach with the Web: Factors influencing teacher education faculty. The Internet and Higher Education, 7(4), 329-341.

Greenberg, L (2002). LMS and LCMS: What's the Difference, Learning Circuits-ASTD_s Online Magazine All About E-Learning, retrieved from http://php.scripts.psu.edu/users/g/m/gms/fa07/IST440W/LMS\%20and\%20LCMS_\%20What\%27s \%20the\%20Difference_pdf on August 18, 2011.

Hazari, S. I. (1998). Evaluation and selection of web course management tools. Retrieved from http://www.sunilhazari.com/education on August 25, 2011.

Haythornthwaite, C. (2000). Online personal networks: size, composition, and media use among distance learners. New Media and Society, 2(2), 195 - 226.

Henderson, A. J.(2003). The e-learning question and answer book: a survival guide for trainers and business managers, American Management Association, 2003.

Horton, W. (2000). Designing web-based training: How to teach anyone anything anywhere anytime. New York: Wiley \& Sons.

Hotchalk (2011) retrieved from http://www.hotchalk.com/index_new.html on August 16, 2011 
Ismail, J. (2002). The design of an e-learning system beyond the hype. Internet and Higher Education, 4, 329336.

Joomla (2011) retrieved from http://www.joomla.org/ on August 16, 2011.

Jonassen, D. H., Peck, K. L. \& Wilson, B. G. (1999). Learning with Technology: A Constructivist Perspective, Prentice-Hall, Englewood Cliffs, NJ.

Kang, S. G., Lee Y. H. \& Kim S. S. (2000). Design of systematic concept learning model using computer education search engine. School Net 2000. 285-298.

Kim, K. \& Bonk, C. (2006). The future of online teaching and learning in higher education. The survey says.... Educause Quarterly, 29(4), 22-30 from http://www.educause.edu/EDUCAUSE+Quarterly/EDUCAUSEQuarterlyMagazineVolum/TheFutureo fOnlineTeachingandLe/157426 on 14 August, 2011.

Kim, S. W. \& Lee, M. G. (2007). Validation of an evaluation model for learning management systems. Journal of Computer Assisted Learning, 24, 284-294.

Lee, J. (2001). Instructional support for distance education and faculty motivation, commitment and satisfaction. British Journal of Educational Technology, 32, 2. 153-60.

Lewis, M., DeLaCruz, E., Jeffrey, T. \& Wilson, W. (2005). Learning Management Systems Comparison, Proceedings of the 2005 Informing Science and IT Education Joint Conference, Flagstaff, Arizona, USA - June 16-19, 17-29.

McConachie, J., Danaher, P. A., Luck, J. T. \& Jones, D. (2005). Central Queensland University's course management systems: Accelerator or brake in engaging change? International Review of Research in Open and Distance Learning, 6(1). Retrieved from http://www.irrodl.org/index.php/irrodl/article/viewArticle/219/302 on August 28,2011.

McConnell, D. (2005). Examining the dynamics of networked elearning groups and communities. Studies in Higher Education, 30(1), 25-42.

Messing, J. (2002). Can academics afford to use e-mail. E-journal of instructional Science and Technology, 5(2).

Middleton, D. (2010). Putting the learning into e-learning. European Political Science, 9, 5-12.

Migadadi, M. M. (2009). A knowledge-centered culture as an antecedent of effective knowledge management at information technology centers in the Jordanian Universities. Journal of Systems and Information Technology, 11(2), 89-116.

Muir-Herzig, R. G. (2004). Technology and its impact in the classroom. Computers and Education, 42(2), 111131.

Naidu, S. (2004). Trends in Faculty Use and Perceptions of E-Learning. Asian Journal of Distance Education, 2(2), retrieved from http://www.asianjde.org/2004v2.2.Naidu.pdf on August 12, 2011.

Oakes, K. (2002). E-learning: LCMS, LMS - They're not Just Acronyms But Powerful Systems for Learning. Training \& Development, 56(3), 73-75.

Peters, 0. (2001). Learning and Teaching in Distance Education, London: Kogan Page.

Watson, W. R. \& Watson, S. L. (2007). What are Learning Management Systems, What are They Not, and What should they Become? TechTrends, 51(2), 28-34.

Yueh, H. \& Hsu, S. (2008). Designing a Learning Management system to Support Instruction. Communications of the ACM, 51(4), 59-63.

Ramaprasad, A. (1983). On the definition of feedback. Behavioral Science, 28, 4-13.

Reigeluth, C. M. \& Garfinkle, R. J. (1994). Envisioning a new system of education. In C. M. Reigeluth \& R. J. Garfinkle (Eds.), Systemic change in education (59-70). Englewood Cliffs, NJ: Educational Technology Publications.

Sadler, D. R. (1989). Formative assessment and the design of instructional systems. Instructional Science, 18, 119-144.

Salajan, F. D., Perschbacher, S., Cash, M., Talwar, R., El-Badrawy, W. \& Mount, G. J. (2009). Learning with webbased interactive objects: an investigation into student perceptions of effectiveness. Computers \& Education, 53(3), 632-43.

Sanchez-Alonso, S. \& Frosch-Wilke, D. (2005). An ontological representation of learning objects and learning designs as codified knowledge. The Learning Organization, 12, 471-479.

Schmidt, K. (2002). The Web-Enhanced Classroom. Journal of Industrial Technology, 18(20, 2-6. retrieved from http://atmae.org/jit/Articles/schmidt011802.pdf on 13 August, 2011.

Selim, H. M. (2007). Critical success factors for e-learning acceptance: Confirmatory factor models. Computers \& Education, 49, 396-413. 
Simonson, M., Smaldino, S., Albright, M. \& Zvacek, S. (2006). Teaching and learning at a distance: Foundations of Distance Education (3rd ed.). Upper Saddle River, NJ: Pearson.

Taylor, F. P. (2004). Education technology helps unite school communities, improve academic achievement. T.H.E. Journal, 31(10), 46-48.

Vrasidas, C. (2004). Issues of Pedagogy and Design in e-learning Systems, 2004 ACM Symposium on Applied Computing, 911-914.

Woods, R., Baker, J. \& Hopper, D. (2004) Hybrid structure: Faculty use and perception of Web-based courseware as a supplement to face-to-face instruction. Internet \& Higher Education, 7, 4, 281-297.

Yang, S. (2008), An ontological website models-supported search agent for web services. Expert Systems with Applications, 35(4), 2056-73.

Yildirim, S., Temur, N., Kocaman, A. \& Goktas, Y. (2004).What makes a good LMS: An analytical approach to assessment of LMSs. In Proceedings of the Fifth International Conference on Information Technology Based Higher Education and Training. (Istanbul, Turkey, May 31-June 2, 2004), 125-130.

Young, J. R. (2002). The 24 hour professor: online teaching redefines faculty members' schedules, duties and relationships with students, The Chronicle of Higher Education, 31 May.

Yueh, H. \& Hsu, S. (2008). Designing a learning management system to support instruction. Communications of the ACM, 51(4), 59-63.

Zhang, D. \& Nunamaker, J. F. (2003). Powering E-Learning In the New Millennium: An Overview of E-Learning and Enabling Technology. Information Systems Frontiers, 5(2), 207-218. 